\title{
Linguistic Hybridity in the Poetry Translation of Hong Lou Meng
}

\author{
Ying Li \\ Foreign Language School \\ Huanghe Science and Technology College \\ Zhengzhou, China
}

\begin{abstract}
Hong Lou Meng is regarded as one of the "Four Great Classical Chinese Novels", and there have been many translated versions of Hong Lou Meng. Hybridity theory claims that all the translated versions are hybrid texts. The paper aims to investigate the linguistic hybridity phenomenon of the poetry translation in Hong Lou Meng from lexical and Syntactic aspect, by comparing its two full-text translated versions (the Yangs' version and Hawkes' version).
\end{abstract}

Keywords-Hong Lou Meng; hybridity theory; poetry translation

\section{THE BRIEF INTRODUCTION OF HYBRIDITY THEORY AND HONG LOU MENG}

Post-colonialism was initiated in 1970s, and has been widely concerned in the academic researches. It rapidly becomes one of the most influential literary and cultural theories. Homi K. Bhabha, one of the outstanding representatives of postcolonialism, put forward the famous "hybridity theory", aiming to deconstruct and demystify the classical canon of the Western imperial colonialism, to resist the Euro-American cultural hegemony, to diminish the West centrism, to eliminate the binary opposition, and to reconstruct the subjectivity of the Subaltern and the "minorities" or the weak culture with the aspiration to help them find their own cultural identity. [1]

Hong Lou Meng is a fairy blossom in the garden of world literature. The author Cao Xueqin, with his own experience and his remarkable writing skills, presents before readers a vivid and realistic history of the declining feudal society. Hong Lou Meng is abundant in contents, including many such aspects as the art of architecture, food culture, medicine, health preserving, custom, etiquette, poetry, all forms of life and so on, due to which it is considered as the encyclopedia for studying the ancient Chinese literature and culture.

Hong Lou Meng has been translated into many languages in the worldwide, but most of them are selected translations. This paper mainly focuses on two full-text translated English versions: one is The Story of the Stone translated by David Hawkes and John Minford, the other is A Dream of Red Mansions translated by Yang Xianyi and Gladys Yang. Hybridity theory claims that all translated versions are hybrid texts, whose differences lie in the degrees of hybridity.The present paper, based upon the 'Hybridity Theory', will be conducted by comparing and analyzing the two full-text versions so as to investigate the linguistic hybridity phenomenon of the poetry translation in Hong Lou Meng from lexical and Syntactic aspect.

\section{LINGUISTIC HYBRIDITY IN THE POETRY TRANSLATION OF HONG LOU MENG}

\section{A. Lexical Hybridity}

In chapter three, Baoyu and Daiyu meet each other for the first time. Cao Xueqin gives a vivid description about Jia Baoyu with a poem named "Xi Jiang Yue". Here are some lines from it.

\section{……富贵不知乐业, 贫困难耐凄凉。可怜幸负好时光,} 于国于家无望。

a. Version by the Yangs:

Left cold by riches and nobility,

Unfit to bear the stings of poverty,

He wastes his time and his ability,

Failing his country and his family. [3]

b. Version by Hawkes and Minford:

Prosperous, he could not play his part with grace,

Nor, poor bear hardship with a smiling face.

So shamefully the precious hours he'd waste,

That both indoors and out he has disgraced. [4]

In ancient Chinese, words like 富, 贵, 国 and 家, bear their own independent meanings respectively, which are different from the modern Chinese. Yang Xianyi has a very good command of ancient Chinese, while Hawkes, although he had a rich knowledge of Chinese language and culture, he 
may still be confused sometimes. In the whole process of translation, understanding is the first step, without correct understanding, there would be no good translation. The Yangs translated “富贵” into “riches” and “nobility”, “国与家” into "country" and "family", while for Hawkes, it is very difficult for him to recognize these tiny differences, so he just simply translated them into "prosperous" and "indoors and out", which failed to transmit the meaning of the original text. Therefore, from the perspective of lexical hybridity, the Yangs kept more heterogeneous elements of the original poem, and of course their version has high degree of hybridity, while Hawkes's version has low degree of hybridity.

In chapter sixty-four, Lin Daiyu writes down five poems to express her sadness and pity for the miserable endings of five beauties in ancient times. Here is one of them:

\section{五美吟・虞姬 \\ 断肠乌雅夜啸风, 虞兮幽恨对重睲。 \\ 點彭甘受他年酭, 饮剑何如楚帐中。}

a. Version by the Yangs:

Lady Yu

Heart-broken as black steed neighing at night in the wind,

In silent grief she stayed beside her lord;

The renegades Qing Bu and Peng Yue were doomed to be slaughtered;

Better, then, in Chu's tent to fall on her own sword [3].

b. Version by Hawkes and Minford:

Yu Ji air.

The very crows are grieving as they caw in the cold night

She faces her beaten Tyrant King with a haggard look of despair:

Let the others wait for the hangman, to be hacked and quartered and rent;

Better the taste of one's own steel in the decent dark of a tent[4].

In this poem, there is a story about the battle between Liu Bang and Xiang $\mathrm{Yu}$ in Gaixia. Xiang $\mathrm{Yu}$ is defeated, and commits suicide after Yu Ji's suicide. Qing Bu and Peng Yue, who were subordinates of Xiang $\mathrm{Yu}$, later betrayed him and were finally slaughtered by Liu Bang. By comparing the different endings of these four persons (“虞” refers to $\mathrm{Yu} \mathrm{Ji}$, “重瞳”refers to Xiang Yu, “黥彭”refer to Qing Bu and Peng Yue), Lin Daiyu speaks highly to Yu Ji's love and loyal to Xiang Yu.

In the Yangs translation, in order to maintain the heterogeneous elements of the source text in the target text, they use "heart-broken black steed", "In silent grief", "Qing Bu and Peng Yue", "Chu's tent", "fall on her own sword", and etc. Their version successfully transmit the otherness of the original text into the English language and culture. On the contrary, in Hawkes's version, some cultural points are misunderstood or even omitted, for instance “乌雅” is translated as “crow”, “重瞳” is omitted, “黥彭” is simply replaced by “the others", and “饮剑” and “楚帐” are respectively translated as "the taste of one's own steel" and "the decent dark of a tent", all of which are not adequate translation.

From the example mentioned above, it can be easily found that in the Yangs' version, the degree of hybridity is much higher than that in Hawkes's. And also, when translating words with culture specialty, if translated under the guidance of hybridity strategy, it could bring new elements, making English no more as pure as what the foreign readers used to see, and defying the authority of English language and culture. This will help to rewrite the superior culture and hybridize it with the inferior culture so as to weaken and dethrone the authority of the former and enable the inferior culture to get its legitimate identity. Meanwhile, this kind of translation helps to enhance readers' sense of cultural difference and promote the equal communication between different cultures [5].

\section{B. Syntactic Hybridity}

In chapter seventeen, when playing in the Grand View Garden, Baoyu is caught by his father and forced to compose some poems by which to test his talents. The following poem is one of them.

\section{宝鼎茶闲烟尚绿，}

幽窗棋罢指犹凉。

a. Version by the Yangs:

"Still green the smoke from tea brewed in a rare tripod;

Yet cold the fingers from chess played by quiet window." [3]

b. Version by Hawkes and Minford:

"From the empty cauldron the steam still rises after the brewing of tea.

By the darkening window the fingers are still cold after the game of Go." [4]

In the original poem, two lines are well structured with the neat antithesis, such as “宝鼎” and “幽窗”, “茶闲” and “棋罢”, “烟尚绿” and “指犹凉”. This kind of description puts readers into an elegant and serene environment, by which to reflect the emerald of the bamboos outside the window of "Xiaoxiang House". The Yangs' version adopts the quiescent description and renders “茶闲”, “棋罢” into “tea brewed” and "chess played", successfully transmitting the meanings of the original poem. In addition, the Yangs put "Still green the smoke" and "Yet cold the fingers" to put stress on the “烟尚 绿” and “指犹凉”, achieving satisfactory effects. While 
Hawkes adopts dynamic description, for example, he uses "the steam rises" and "the darkening window". In addition, Hawkes adopts the iambic hexapody, which makes the translation long-winded. This distinction may be aroused by the linguistic and cultural differences, which sometimes are beyond translators' control, but from the angle of hybridity in translation, the Yangs' version is better than Hawkes's version.

In chapter twenty-eight, Baoyu was drinking outside with some friends. During drinking, Baoyu composed a poem to express a girl's lovesickness. The poem goes like this:

\section{《红豆曲》}

女儿悲, 青春已大守空闺。女儿愁, 悔教夫婿受封侯。 女儿喜，对镜晨妆颜色美。女儿乐，秋千架上春衫薄。 滴不尽相思血泪抛红豆, 开不完春柳春花满画楼。 睡不稳纱窗风雨黄昏后, 忘不了新愁与旧愁。

咽不下玉粒金莼噎满喉，照不尽菱花镜里形容瘦。 展不开的眉头, 捱不明的更漏。

呀, 恰便是遮不住的青山隐隐, 流不尽的绿水悠悠。 “雨打梨花深闭门”。

a. Version by the Yangs:

The girl's sorrow: Youth is passing but she remains single.

"The girl's worry: Her husband leaves home to make his fortune

"The girl's joy: Her good looks in the mirror in the morning.

"The girl's delight: Swinging in a light spring gown."

Like drops of blood fall endless tears of longing,

By painted pavilion grow willows and flowers untold;

Sleepless at night when wind and rain lash gauze windows,

She cannot forget her sorrows new and old;

Choking on rice like jade and wine like gold,

She turns from her wan reflection in the glass;

Nothing can smooth away her frown,

It seems that the long night will never pass;

Like the shadow of peaks, her grief is never gone;

Like the green stream it flows for ever on.

"Rain buffets the pear blossom and the door is closed". [3]

b. Version by Hawkes and Minford:

The girl's upset:
The years pass by, but no one's claimed her yet.

The girl looks glum:

Her true-love's gone to follow ambition's drum.

The girl feels blest:

The mirror shows her looks are at their best.

The girl's content:

Long summer days in pleasant pastimes spent.

'Still weeping tears of blood about our separation:

Little red love-beans of my desolation.

Still blooming flowers I see outside my window growing.

Still awake in the dark I hear the wind a-blowing.

Still oh still I can't forget those old hopes and fears.

Still can't swallow food and drink, 'cos I'm choked with tears.

Mirror, mirror on the wall, tell me it's not true:

Do I look so thin and pale, do I look so blue?

Mirror, mirror, this long night bow shall I get through?

Oh-oh-oh!

Blue as the mist upon the distant mountains,

Blue as the water in the ever-flowing fountains.'

"Rain whips the pear-tree, shut fast the door". [4]

According to the rule, the poem composers have to use four words like “女儿悲” “女儿愁” “女儿喜” “女儿乐” to express a girl's complicated feelings at the beginning of a poem. Baoyu composes this poem to show a kind of lovesickness. Comparing the two versions, Yang's version is closer to the original poem than Hawkes's version. For instance, “女儿悲” “女儿愁” “女儿喜” “女儿乐” are translated into "the girl's sorrow", "the girl's worry", "the girl's joy", "the girl's delight", while Hawkes renders them into "the girl's upset", "the girl looks glum", "the girl feels blest”, “the girl's content”. “咽不下玉粒金莼噎满喉, 照不 尽菱花镜里形容瘦”, these two lines, Yang's version attempts to keep the features of the original poem, but Hawkes's version adopts the domestication strategy by using "Do I look so thin and pale, do I look so blue? Mirror, mirror, this long night bow shall I get through?" However, in the translation of another four phrases like “滴不尽”, “开不完”, “睡不稳”, “忘不了”, Hawkes's version are "Still weeping”, "Still blooming", "Still awake", "still I can't forget" which are 
obviously better than Yang's version. In short, in the translation of this poem, two versions both have their strong points, however, generally speaking, Yang's version is better suited for introducing Chinese classical culture to English readers, and therefore, his version enjoys higher degree in terms of translation hybridity.

\section{CONCLUSION}

From what we mentioned above, we can easily find that linguistic hybridity is naturally feasible in the translation of poems from Hong Lou Meng; it can help maintain the beauty of the classical Chinese poetry, maintain the otherness of the Chinese version, and introduce Chinese culture to the English readers. However, the degree of hybridity in translation is not easy to control, because it is influenced by many factors, such as the translator's subjectivity, types of source text, readers, social cultural factors and other factors. Therefore, to what degree should the translation be kept and how to keep an appropriate degree of hybridity in translation become key issues for translation scholars to concentrate on. For the research of literature translation, only hybridity theory is not sufficient, and "there needs to be other methods and approaches as its supplements" [5].

\section{REFERENCES}

[1] Li Ying, An Investigation into the Hybridity Phenomenon of Poetry Translation in Hong Lou Meng, kai feng: Atlantis Press, 2015

[2] Cao X Q, Gao E: Hong Lou Meng, Beijing: People's Literature Publishing House, 1964.

[3] Cao X Q, “A Dream of Red Mansions" . Transl.Yang X Y, Yang G, Beijing: Foreign language Press, 2003

[4] Cao X Q. "The Story of the Stone" Transl. Hawkes D, London: Penguin, 1973.

[5] Zhang Zhiqiang. P.S. Buck's Version of Shui Hu Zhuan in the Light of the Post-colonial Translation Theory[J]. Chinese Translators Journal, 2010(2). 